\title{
The Endothelium and Its Role in Regulating Vascular Tone
}

\author{
Aamer Sandoo ${ }^{1,2, *}$, Jet J.C.S. Veldhuijzen van Zanten $^{1,2}$, George S. Metsios ${ }^{2}$, Douglas Carroll ${ }^{1}$ \\ and George D. Kitas ${ }^{1,2}$ \\ ${ }^{1}$ School of Sport and Exercise Sciences, University of Birmingham, Birmingham, West Midlands, United Kingdom \\ ${ }^{2}$ Department of Rheumatology, Dudley Group of Hospitals NHS Trust, Russell's Hall Hospital, Dudley, West Midlands, \\ United Kingdom
}

\begin{abstract}
The endothelium forms an important part of the vasculature and is involved in promoting an atheroprotective environment via the complementary actions of endothelial cell-derived vasoactive factors. Disruption of vascular homeostasis can lead to the development of endothelial dysfunction which in turn contributes to the early and late stages of atherosclerosis. In recent years an increasing number of non-invasive vascular tests have been developed to assess vascular structure and function in different clinical populations. The present review aims to provide an insight into the anatomy of the vasculature as well as the underlying endothelial cell physiology. In addition, an in-depth overview of the current methods used to assess vascular function and structure is provided as well as their link to certain clinical populations.
\end{abstract}

Keywords: Endothelium, Smooth muscle, Nitric Oxide, Endothelial Dysfunction, Cardiovascular Disease, Atherosclerosis, Microvascular, Macrovascular.

\section{THE ENDOTHELIUM}

Once considered as a simple barrier between the blood and vessel wall, the endothelium is now regarded as a dynamic organ which lines the entire vascular system [1]. Endothelial cells are located on the intima - which is the inner lining of the vasculature and they control vascular function by responding to various hormones, neurotransmitters and vasoactive factors which affect vasomotion, thrombosis, platelet aggregation and inflammation [1]. The balanced production of these vasoactive factors is atheroprotective, whereas a damaged endothelium causes disrupted production of these factors. The ensuing imbalance leads to endothelial dysfunction (ED), which is an early indicator of atherosclerosis [2]. Endothelial cells are located on the intima of all vessels (described in detail below), but display different structures and phenotypes depending on vessel type [3]. Endothelial cells in arteries and veins appear more continuous and thicker than those in capillaries which are fenestrated and thinner to allow for exchange of metabolites and gases [4]. In addition, endothelial cells can display heterogeneous responses to stimulation in different vascular beds, and even in different sections of the same vascular bed [5-7]. This suggests that ED may occur in selective vascular beds too [7].

\section{ANATOMY AND PHYSIOLOGY OF THE BLOOD VESSELS}

The blood vessels provide the main link between the heart and the tissues. The vascular wall is made up of three

*Address correspondence to this author at the Dudley Group of Hospitals NHS Foundation Trust Clinical Research Unit, 1st Floor North Block Russells Hall Hospital, Dudley, DY1 2HQ, UK; Tel: (+44) 01384456111 ext 3717; E-mail: aamer.sandoo@dgoh.nhs.uk layers; the intima (inner layer), the tunica media (middle layer) and the tunica externa (outer layer) [8]. The blood vessels are divided depending on function, location and size into arteries, capillaries and veins.

\section{VASCULAR ANATOMY}

The main function of the arteries is to supply the organs with blood. Given the high pulse pressure in the arteries their walls are thicker than in other vessels. Arteries can be divided into conducting arteries, conduit arteries and resistance arteries based on their position in the arterial tree. Conducting arteries are the largest arteries in the body and have a large amount of elastic tissue which allows the vessel to expand and recoil to dampen out the oscillatory changes in blood pressure as a result of intermittent ventricular contractions. Examples of conducting arteries include the aorta, pulmonary artery and carotid artery [9]. Conducting arteries branch into conduit arteries such as the brachial, radial and femoral arteries, and the function of these arteries is to direct blood to specific regions of the body [10]. The conduit arteries further divide into the resistance arteries which are responsible for adequately perfusing the organ tissue with blood and form part of the microcirculation. They consist mainly of smooth muscle cells which are highly innervated by sympathetic nerves, allowing the arterioles to regulate bloodflow to the tissue by dilating or constricting in response to sympathetic (de)activation [4]. Another stimulus that can cause dilation of arterioles is shear stress (the dragging frictional force exerted on the vessel wall by laminar blood flow) [11]. The site of tissue perfusion occurs in the capillaries, which like arterioles are part of the microcirculation [4]. The main function of the capillaries is to enhance the diffusion of gases, metabolites and nutrients between the blood and the tissue. This is achieved by capillary walls which 
consist of a single layer of endothelial cells, thus, shortening the diffusion pathway between the blood and tissue fluid. Efficiency of diffusion is further enhanced by the slow bloodflow which helps to increase the time available for diffusion [12]. Once gaseous exchange occurs, the blood containing metabolites flows into venules - where further gaseous exchange may also take place. The venules feed into the peripheral veins and then into the superior and inferior vena cavae, which are connected to the heart. In general, the diameter of veins increases with increased proximity to the heart. Given the lower blood pressure in the venous system compared to the arterial system, the vessel walls of veins are thinner and more compliant than arterial walls. This means that veins can accommodate large volumes of blood with only small increases in pressure. Mechanisms such as the skeletal muscle pump and respiratory pump as well as sympathetic nervous activation enable veins to return blood back to the heart. In addition, veins contain valves to prevent backflow of blood while smooth muscle cells in the vascular wall allow veins to constrict and increase the blood pressure, both of which increase venous return [13].

\section{REGULATION OF VASCULAR TONE}

The endothelium releases various vasoactive factors. These can be vasodilatory factors such as nitric oxide (NO), prostacyclin $\left(\mathrm{PGI}_{2}\right)$ and endothelium derived hyperpolarizing factor (EDHF) or vasoconstrictive factors such as thromboxane $\left(\mathrm{TXA}_{2}\right)$ and endothelin-1 (ET-1). These factors are discussed in greater detail below.

\section{a) Nitric Oxide}

Nitric oxide (NO) is an endothelium-dependent vasodilator of the underlying smooth muscle and was first identified by Furchgott and Zawadzki [14]. NO has been shown to play an important role in the maintenance of basal vasodilator tone of the blood vessels [15]. NO is formed under the influence of the enzyme nitric oxide synthase (NOS), which con-

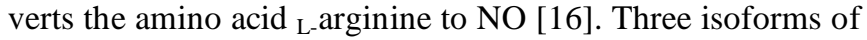
NOS exist: neuronal isoform (nNOS) which produces NO to act as a neuronal messenger that regulates synaptic neurotransmitter release [17], macrophage or inducible isoform (iNOS) which is only expressed in cells that have been exposed to inflammatory mediators or other injurious stimuli that activate the macrophages [18], and endothelial NOS (eNOS) which produces nitric oxide in the vasculature [19]. The isoforms are classified by the cells they were originally found in, although, it is now known that expression of these isoforms also occurs in other cells, such as cardiac myocytes [20], skeletal muscle, blood platelets and the hippocampus [21]. Considering that the ability of a blood vessel to dilate is largely dependent upon the activity of eNOS, the present discussion will focus on this isoform.

Inactive eNOS is bound to the protein caveolin and is located in small invaginations in the cell membrane called caveolae [22]. When intracellular levels of $\mathrm{Ca}^{2+}$ increase, eNOS detaches from caveolin and is activated [22]. NO agonists can influence the detachment of eNOS from caveolin by releasing $\mathrm{Ca}^{2+}$ from the endoplasmic reticulum (Fig. 1) [23]. Examples of such NO agonists include bradykinin (BK), acetylcholine (ACh), adenosine tri-phosphate (ATP), adenosine di-phosphate (ADP), substance $\mathrm{P}$ and thrombin
[24]. Once intracellular $\mathrm{Ca}^{2+}$ stores are depleted a signal (thus far unidentified) is sent to the membrane receptors to open $\mathrm{Ca}^{2+}$ channels allowing extracellular $\mathrm{Ca}^{2+}$ into the cell $[25,26]$. This process of $\mathrm{Ca}^{2+}$ regulation is known as storeoperated $\mathrm{Ca}^{2+}$ entry or capacitative $\mathrm{Ca}^{2+}$ entry [27]. $\mathrm{Ca}^{2+}$ attaches to the protein calmodulin in the cytoplasm of the cell, after which it undergoes structural changes which allows it to bind to eNOS [28]. eNOS then converts $\mathrm{L}_{\mathrm{H}}$-arginine into NO [16]. This pathway of NO production is represented in Fig. (1) below. It is important to highlight that this mechanism of NO production is dependent on the levels of intracellular $\mathrm{Ca}^{2+}$ in the endoplasmic reticulum as well as $\mathrm{Ca}^{2+}$ which diffuses into the cell from extracellular stores. A reduction in $\mathrm{Ca}^{2+}$ causes the calcium-calmodulin complex to dissociate from eNOS, which in turn binds with caveolin and becomes inactivated [28].

The short term increase in NO is dependent on the intracellular $\mathrm{Ca}^{2+}$ but once this decreases additional mechanisms are activated to regulate NO production. One such mechanism is the phosphorylation of eNOS [29]. Phosphorylation of eNOS occurs via protein kinases [18], such as protein kinase A [23] and cyclic guanosine-3', 5-monophosphate (cGMP) protein kinase dependent II [29]. Shear stress initiates eNOS phosphorylation by the actions of protein kinase $\mathrm{B}$ (Akt) [30].

Shear stress results from increased bloodflow in the vessel and can increase NO production by eNOS phosphorylation but also through stimulating endothelial cell receptors by allowing the transfer of blood-borne agonists to attach to endothelial cell receptors and increase intracellular $\mathrm{Ca}^{2+}[31]$. In particular, shear stress activates specialised $\mathrm{Ca}^{2+}$-activated $\mathrm{K}^{+}$channels on the endothelial cell surface, causing $\mathrm{K}^{+}$efflux and $\mathrm{Ca}^{2+}$ influx into the cell [32] (Fig. 1). The contribution of $\mathrm{Ca}^{2+}$ and eNOS phosphorylation to NO production is dependent on the duration of the shear stress. For example, intracellular $\mathrm{Ca}^{2+}$ release is dependent on shear stress of short durations [33], whereas shear stress of longer durations $(>30$ minutes) can deplete intracellular $\mathrm{Ca}^{2+}$ stores, and so NO production is dependent on eNOS phosphorylation [34].

Once synthesized, NO diffuses across the endothelial cell into the adjacent smooth muscle (Fig. 1), where it binds to the enzyme soluble guanylyl cyclase (sGC) [35]. The now activated enzyme increases the conversion rate of guanosine triphosphate (GTP) to cGMP, which decreases smooth muscle tension [36]. Further, cGMP reduces $\mathrm{Ca}^{2+}$ release from the sarcoplasmic reticulum in the smooth muscle cell [37], and also helps to restore $\mathrm{Ca}^{2+}$ to the sarcoplasmic reticulum [38]. Both actions reduce the contraction of smooth muscle cells.

The mechanisms described above are continuously active and produce NO to maintain basal vasodilator tone. By inhibiting $\mathrm{NO}$ activity using $\mathrm{N}^{\mathrm{G}}$ monomethyl-L-arginine (LNMMA), a dose dependent increase in blood pressure was found due to the vessels constricting, which was reversed when NO was administered [39]. These findings highlight the importance of $\mathrm{NO}$ in maintaining resting vasodilator tone. However, the vessel is also capable of dilating in the absence of NO. After removal of or damage to the endothelium, administration of glyceryl trinitrate (GTN) can still result in vasodilatation [15]. 


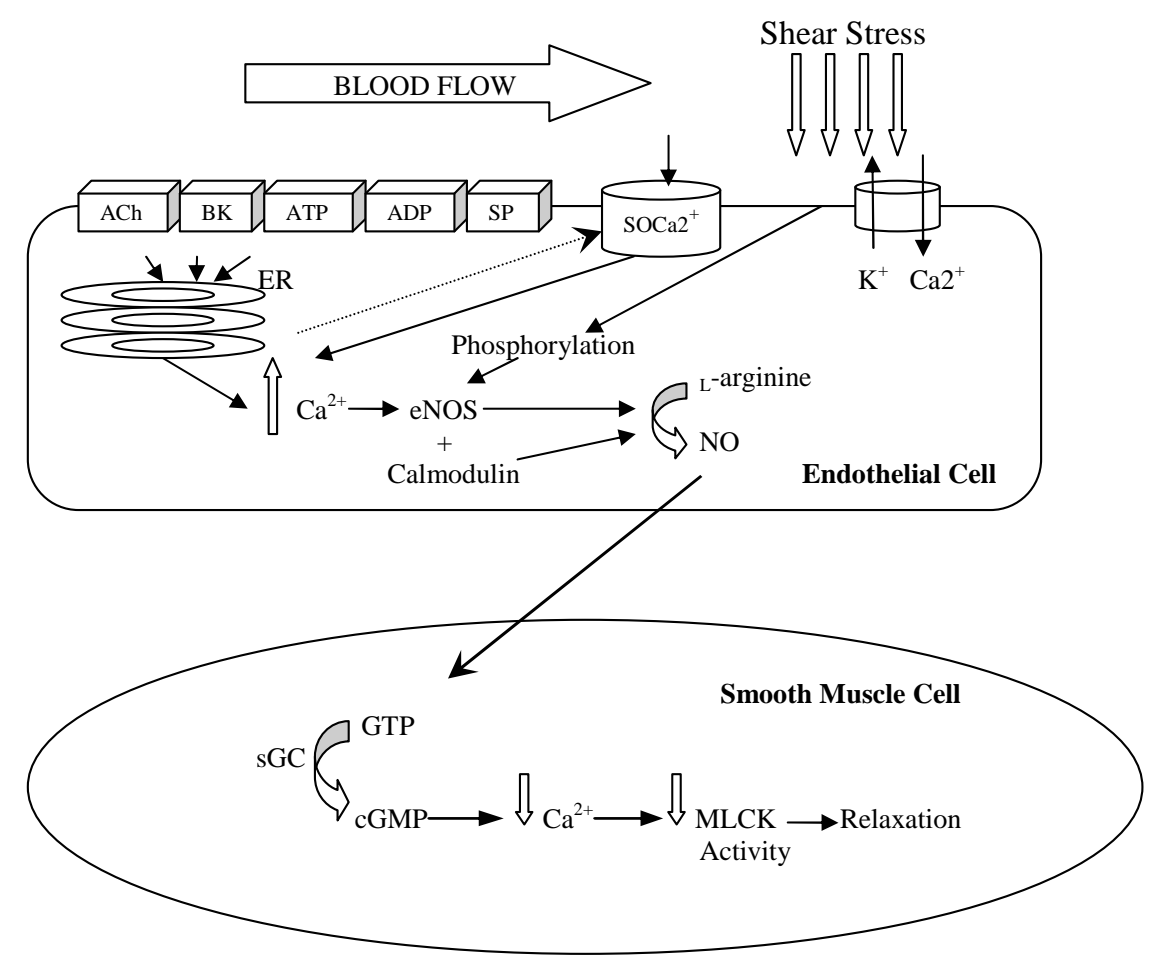

Fig. (1). Endothelial nitric oxide production and it actions in the vascular smooth muscle cell. $\mathrm{ACh}=$ acetylcholine; $\mathrm{BK}=\mathrm{bradykinin} ; \mathrm{ATP}=$ adenosine triphosphate; $\mathrm{ADP}=$ adenosine diphosphate; $\mathrm{SP}=$ substance $\mathrm{P} ; \mathrm{SOCa}^{2+}=$ store-operated $\mathrm{Ca}^{2+}$ channel; $\mathrm{ER}=$ endoplasmic reticulum; $\mathrm{NO}=$ nitric oxide; $\mathrm{sGC}=$ soluble guanylyl cyclase; cGMP= cyclic guanosine-3', 5-monophosphate; MLCK= myosin light chain kinase . *When $\mathrm{Ca}^{2+}$ stores of the endoplasmic reticulum are depleted a signal is sent to $\mathrm{SOCa}^{2+}$ channel which allows extracellular $\mathrm{Ca}^{2+}$ into the endothelial cell.

The mechanism by which GTN causes vasodilatation is not clear. Several researchers have suggested that GTN undergoes bioconversion to NO [40-42], but not all agree, as GTN has been found to cause vasodilatation without increasing NO [43]. Further, the breakdown products of GTN have been shown to activate sGC [44]. It is worth noting that other vasoactive agents such as calcium ionophore A23187 and isosorbide-dinitrate induce vasorelaxation without an increase in NO concentration [24]. Therefore, NO does not seem to be the only agent that can activate the sGC-cGMP pathway. Further research is needed to identify the precise mechanism of the agents, in particular, more research is needed in vivo due to the differences in response between intact or a denuded endothelium [1].

Aside from vasodilatation, $\mathrm{NO}$ is also involved in preventing platelet and leukocyte activation and adhesion to the vessel wall $[45,46]$. When the endothelium is damaged, the subsequent inflammation causes an increase in leucocytes at the damaged site [47]. Inflammatory mediators such as TNF$\alpha$, interleukin-1 (IL-1) and chemokines stimulate the release of iNOS [48], which prevents leucocytes from adhering to the endothelium and reduces inflammatory mediators [49], as well as down-regulating and reducing the expression of adhesion molecules [50].

\section{b) Prostacyclin and Thromboxane $A_{2}$}

The synergistic actions of two prostanoids, prostacyclin $\left(\mathrm{PGI}_{2}\right)$ and thromboxane $\left(\mathrm{TXA}_{2}\right)$ also regulate vascular function [51]. Their production is catalysed by cyclooxygenase
(COX) enzymes, of which there are two isoforms COX-1 and COX-2 [52]. COX-1 is expressed continuously in endothelial cells, whereas COX-2 is only expressed when the endothelium is damaged and exposed to inflammatory cytokines [53, 54].

COX-2 converts arachidonic acid to prostaglandin $\mathrm{H}_{2}$ $\left(\mathrm{PGH}_{2}\right)$, which is then synthesised into $\mathrm{PGI}_{2}$ by prostacyclin synthase [55]. $\mathrm{PGI}_{2}$ binds to the prostacyclin receptors (IP) [56], which are located on both platelets and vascular smooth muscle cells [57]. Activation of platelet IP receptors leads to inhibition of platelet aggregation [58]. $\mathrm{PGI}_{2}$ binding to the smooth muscle cell IP receptor activates adenylate cyclase which induces the synthesis of cyclic adenosine monophosphate (cAMP) [59]. cAMP then activates protein kinase A, which allows relaxation of the smooth muscle in the same way as it does for NO $[60,61]$. It is worth noting that in the presence of $\mathrm{NO}$, blocking $\mathrm{PGI}_{2}$ production has no effect on vasodilatation [62]. However, when NO is blocked, the residual dilation is due to increased $\mathrm{PGI}_{2}$ synthesis [63], suggesting that $\mathrm{PGI}_{2}$ plays a compensatory role in dilation of the vessel when $\mathrm{NO}$ is reduced.

In contrast to $\mathrm{PGI}_{2}, \mathrm{TxA}_{2}$ causes platelet aggregation and vasoconstriction [64]. COX-1 converts arachidonic acid to $\mathrm{PGH}_{2}$, after which $\mathrm{TxA}_{2}$ is synthesised by thromboxane synthase [51]. TxA $\mathrm{A}_{2}$ mediates its effects by its actions on thromboxane-prostanoid (TP) receptors which are located on platelets and their activation causes platelet aggregation [53]. The $\mathrm{TP}$ receptor is also found on smooth muscle cells and is in- 
volved in increasing intracellular $\mathrm{Ca}^{2+}$ levels in the smooth muscle, leading to vasoconstriction [65].

The balance in the activity of $\mathrm{PGI}_{2}$ and $\mathrm{TxA}_{2}$ helps to maintain homeostasis in the healthy vessel. The importance of this balance becomes evident when using selective COX-2 inhibitors to reduce inflammation, which decreases the production of $\mathrm{PGI}_{2}$ without affecting the production of $\mathrm{TXA}_{2}$ [66]. Thus, by administrating COX-2 inhibitors, $\mathrm{TXA}_{2}$ will cause vasoconstriction and platelet aggregation which is unopposed by $\mathrm{PGI}_{2}$, increasing the risk for cardiac events [67].

\section{c) Endothelin-1}

Endothelin (ET) is a vasoconstrictor which is expressed in the body in three isoforms, ET-1, ET-2, and ET-3 [68]. Endothelial cells only release ET-1, thus the present discussion will focus only on this isoform. ET-1 is produced by converting Big ET-1 to ET-1 by endothelin converting enzyme [69]. Regulation of ET-1 production as well as its release is stimulated by inflammatory cells such as interleukins and TNF- $\alpha$ and decreased by NO and $\mathrm{PGI}_{2}$ [68]. Shear stress causes a decrease in ET-1 expression, after initially promoting it. ET-1 receptors have been identified both on smooth muscle cells $\left(\mathrm{ET}_{\mathrm{A}}\right.$ and $\left.\mathrm{ET}_{-\mathrm{B} 2}\right)$ and endothelial cells $\left(\mathrm{ET}-{ }_{\mathrm{B} 1}\right)$ $[70,71]$. The distribution of the different ET- 1 receptors is dependent on the type of vascular bed, as veins show a reduced $\mathrm{ET}_{\mathrm{A}}: \mathrm{ET}_{\mathrm{B}}$ receptor ratio compared with arteries [72]. When ET-1 binds to $\mathrm{ET}_{\mathrm{A}}$ or $\mathrm{ET}_{-\mathrm{B} 2}$ receptors, smooth muscle $\mathrm{Ca}^{2+}$ channels open allowing extracellular $\mathrm{Ca}^{2+}$ into the cell. This causes vasoconstriction in a similar way as $\mathrm{TxA}_{2}$. Activation of $\mathrm{ET}_{-\mathrm{B} 1}$ receptors on the endothelium causes vasodilatation by inducing the release of $\mathrm{NO}$ and $\mathrm{PGI}_{2}[73,74]$. In ED, ET-B1 receptors on the endothelial cells are downregulated, while ET-B2 receptors on smooth muscle cells are upregulated, thus enhancing vasoconstriction $[75,76]$.

The effect of each receptor on the vasculature has been explored in patients with heart disease and in healthy participants. Selectively blocking $\mathrm{ET}_{\mathrm{A}}$ receptors in participants with ED reliably leads to vasodilatation [76]. However, blocking both $\mathrm{ET}_{\mathrm{A}}$ and $\mathrm{ET}_{\mathrm{B}}$ receptors in participants with $\mathrm{ED}$ results in greater vasodilatation than blocking $\mathrm{ET}_{\mathrm{A}}$ receptors only [76]. This finding suggests that the upregulation of smooth muscle $\mathrm{ET}_{\mathrm{B}}$ receptors has an additive effect on vasoconstriction in individuals with $\mathrm{ED}[75,76]$. In healthy participants blocking $\mathrm{ET}_{\mathrm{B}}$ receptors leads to vasoconstriction [77], therefore, $\mathrm{ET}_{\mathrm{B}}$ receptors located on the endothelium predominantly regulate endothelial function in this group.

Apart from its vasoactive effects, ET-1 also causes inflammation and smooth muscle cell proliferation in the vessel. Binding of ET-1 to $\mathrm{ET}_{\mathrm{A}}$ receptors activates macrophages, increases neutrophil-vessel wall interactions, and elevates free radical concentrations, all of which lead to ED [78]. ET-1 causes smooth muscle cell proliferation by binding to ET receptors [79] or activating other growth factors such as platelet-derived growth factor [80]. This results in an increase in the intima-media thickness of the vessel wall [81], which can be reduced by blocking ET-1 receptors [82]. In addition, inhibition of $\mathrm{ET}_{\mathrm{A}}$ receptors in diseased vessels can reduce atherosclerosis, which again suggests that $\mathrm{ET}_{\mathrm{A}}$ receptors are active during ED [83].

\section{d) Endothelium-Derived Hyperpolarising Factor}

Endothelium-derived hyperpolarising factor (EDHF) is a yet unidentified vasodilator substance which hyperpolarises the underlying smooth muscle by making the membrane potential of the cell more negative [84]. EDHF is released when endothelial cells are activated by agonists such as $\mathrm{BK}$ and ACh [85]. NO and $\mathrm{PGI}_{2}$ can also dilate the vessel by hyperpolarising the smooth muscle cells, albeit for a short period before the mechanisms discussed above take over [86]. However, when $\mathrm{NO}$ and $\mathrm{PGI}_{2}$ are inhibited hyperpolarisation still occurs, suggesting the involvement of a third hyperpolarising factor [87]. A number of pathways have been implicated in causing the hyperpolarisation. Although the exact pathway is still unknown, attention so far has been paid to three factors in particular.

Activation of endothelial receptors and the subsequent increase in $\mathrm{Ca}^{2+}$ levels causes $\mathrm{K}^{+}$efflux from the cell [88]. The smooth muscle cell responds to changes in the extracellular $\mathrm{K}^{+}$levels and also releases $\mathrm{K}^{+}$out of the smooth muscle cell causing hyperpolarisation [89]. The change in the membrane potential of the smooth muscle cell reduces intracellular $\mathrm{Ca}^{2+}$ levels, resulting in relaxation [88].

Epoxyeicosatrienoic acids (EET) are products of arachidonic acid metabolism [90]. Although synthesised in the endothelial cell, they act by increasing $\mathrm{K}^{+}$efflux from the smooth muscle cells resulting in hyperpolarisation and relaxation [91, 92]. However, in vessels where EET activity is inhibited, hyperpolarisation still occurs [93], suggesting that other mechanisms must be involved in hyperpolarising the smooth muscle cells.

Gap junctions are intercellular channels which can transfer signals from the endothelial cells to the smooth muscle cells [94]. In particular, gap junctions may transfer $\mathrm{K}^{+}$ions from the smooth muscle cells into the endothelial cell [95]. However, since most studies have only transferred artificial dye between the two cells it is difficult to establish exactly what is transferred under normal conditions.

\section{TECHNIQUES TO ASSESS ENDOTHELIAL FUNCTION}

Endothelial function is most commonly assessed in the peripheral circulation as direct assessment of endothelial function in the coronary arteries is highly invasive and associated with considerable risk for the participant. Several studies have reported close correlations between peripheral and coronary endothelial function [96-98]. In addition, assessments of endothelial function are good predictors of future cardiac events in individuals at risk of CVD and those with established CVD [99, 100], and ED is common in individuals with CVD risk factors [101]. Most assessments of endothelial function involve the measurement of dilation in response to a stimulus, with impaired vasodilatation indicative of poor endothelial function. However, impaired vasodilatation can be the result of either the endothelium not sending the signals to the smooth muscle or of the smooth muscle cells not being able to respond to the signal and dilate. Therefore, in order to distinguish between ED and smooth muscle dysfunction, endothelium-dependent and endothelium-independent vasodilatation are typically assessed. Techniques that assess endothelial function in differ- 
ent vascular beds is shown in Fig. (2) and described in more detail below.

\section{ASSESSMENT OF MICROVASCULAR ENDOTHE- LIAL FUNCTION}

\section{a) Iontophoresis}

The assessment of NO bioavailability in the microvasculature is conducted using iontophoresis [102]. Iontophoresis uses a small electrical current to pass negatively and positively charged vasoactive agents through the skin into the resistance vessels on the basis that like charges repel each other [103]. The amount of the agent that is delivered to the vessel depends on the density and duration of the current. The two most common agents used to test endothelial function are ACh and SNP [104]. The assessment is usually carried out in the forearm. Laser Doppler techniques are used to assess the perfusion in response to iontophoresis. Laser Doppler flowmetry (LDF) assesses perfusion of the vessel over a single point on the forearm [105]. Perfusion can also be assessed by Laser Doppler imaging (LDI) which uses the same principles as LDF, but rather than scanning one point, a whole area of the forearm can be assessed [106].

The ACh and SNP are administered in small chambers which are attached to the volar aspect of the forearm by watertight adhesive pads. The anodal chamber contains $\mathrm{ACh}$, while SNP is present in the cathodal chamber. Both chambers are connected to an iontophoresis controller which delivers the current [105]. The vasoactive agents can be dissolved in fluid known as vehicles, e.g. deionised water or saline. However, these vehicles can also increase skin perfusion [107]. It has been suggested that use of a lower current density reduces the vasodilatory effects of the vehicles, but drug administration is also reduced [108]. However, a higher current density can be used with $0.5 \%$ sodium chloride $(\mathrm{NaCl})$, as it does not elicit a vasodilatory response at this concentration [107]. External factors such as time of day, and menstrual cycle can affect microvascular bloodflow $[109,110]$. Therefore, it is advisable to follow established guidelines when administering this test [111].

\section{b) Forearm Blood Flow and Venous Occlusion Plethysmography}

Endothelial function of the forearm resistance vessels can be assessed using venous occlusion plethysmography (VOP) [112]. This assessment stops venous return from the forearm, while allowing arterial inflow; blood can enter the forearm but cannot escape resulting in a linear increase in forearm volume with time which is proportional to the incoming arterial blood flow [112]. The halt in venous return is achieved by inflating a blood pressure cuff placed around the forearm to below the diastolic blood pressure (typically $40 \mathrm{mmHg}$ ) for 10 seconds, followed by 5 seconds of cuff deflation. The hand is excluded from the measurement by inflating a blood pressure cuff which is placed around the wrist to suprasystolic pressures. This reduces the variation in blood volume due to a high proportion of skin blood vessels susceptible to temperature variations. VOP can be assessed using automated equipment which can precisely control the time for cuff inflation and deflation. The increase in forearm volume is assessed by mercury in rubber strain-gauge plethysmograph placed around the widest part of forearm. An increase in the length of the strain-gauge is detected by a change in electrical resistance and represents an increase in forearm blood flow (FBF). It is also important to assess FBF in the contra-lateral arm so that time-dependent changes in basal blood flow due to arterial pressure fluctuations can be accounted for [112]. The FBF response can also be assessed

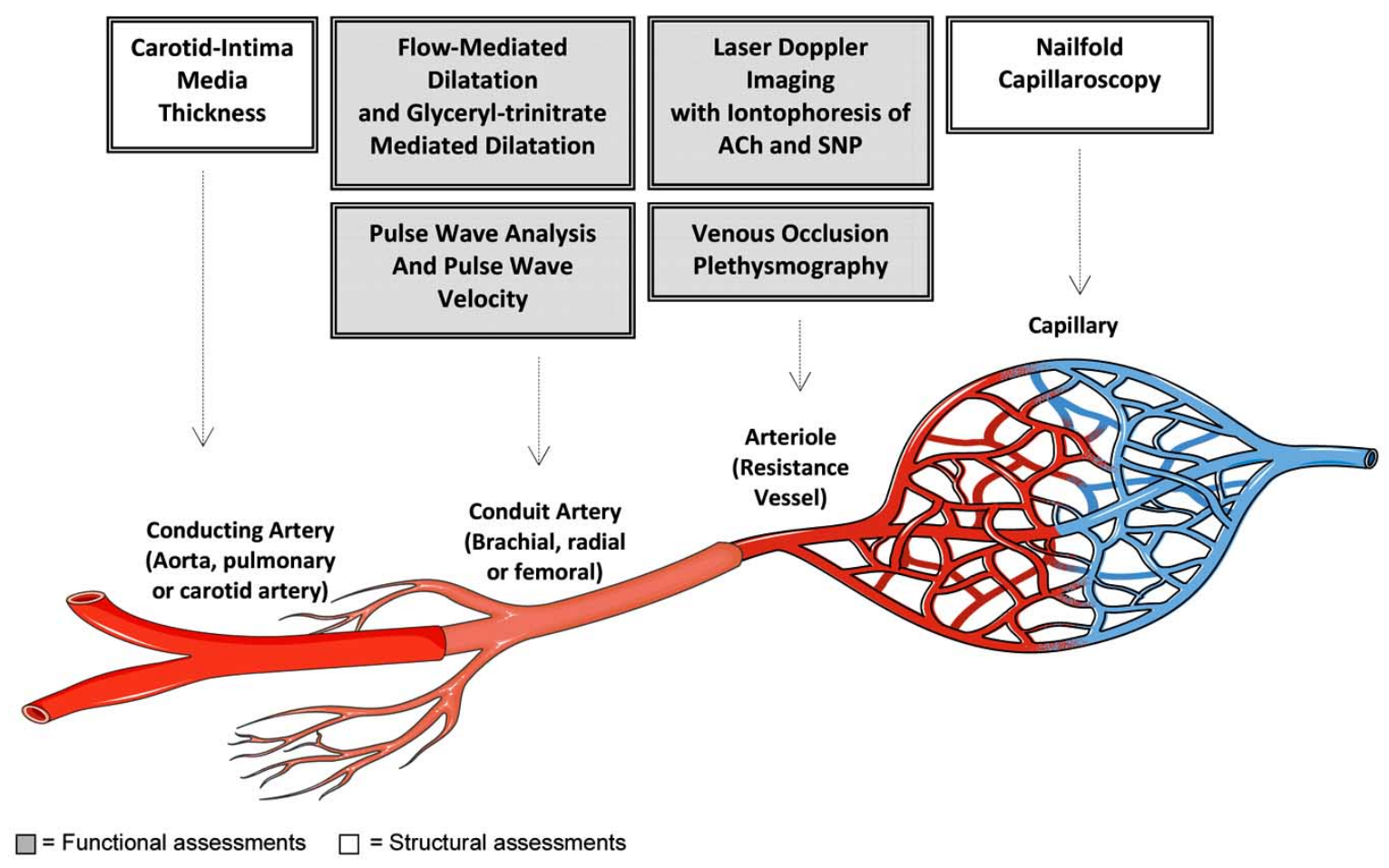

Fig. (2). An overview of the assessments for endothelial function and vascular structure performed in different vascular beds. ACh = Acetylcholine, SNP = Sodium nitroprusside. 
in response to Intra-brachial infusion of various vasoactive agonists (ACh, substance $\mathrm{P}$, bradykinin) or antagonists (LNMMA, indomethacin) [113].

\section{c) Nailfold Capillaroscopy}

Nailfold capillaroscopy is a technique to assess capillary structure [114]. The technique involves the application of immersion oil to the nailfold epidermis of all ten fingers. The nailfold is then placed under a microscope and abnormalities in the capillaries are characterised according to their size, number and structural characteristics. Capillaroscopic abnormalities can be classified into three stages (early, active and late). The earliest change to capillary structure is an enlargement in their size. A reduction in capillary number and structural impairments are seen in the active and later stages of microangiopathy [114].

\section{ASSESSMENT OF MACROVASCULAR ENDOTHELIAL FUNCTION}

\section{a) Flow-Mediated Dilatation}

Flow-mediated dilatation (FMD) is a technique that increases blood flow through an artery to cause vasodilatation on the principal that the increased bloodflow produces shear forces on the endothelium and subsequently stimulates endothelial cells to release NO [30]. As indicated previously, reduced vasodilatation following an increase in shear forces is representative of impaired NO bioavailability [115]. Therefore, FMD is a good surrogate marker of NO bioavailability. The FMD protocol involves a 2 minute baseline ultrasound scan of the brachial artery, after which a cuff placed around the wrist is inflated to $300 \mathrm{mmHg}$ for 5 minutes. This causes tissue ischemia and dilation of downstream resistance vessels via auto-regulatory mechanisms. When the cuff is released a sudden increase in bloodflow (reactive hyperaemia) through the brachial artery fills the dilated resistance vessels and in doing so exerts shear stress on the endothelial cells [116]. The resulting dilation, which peaks at 60-90 seconds after cuff release is dependent on NO activity [117]. FMD is expressed as the maximum percentage change in vessel diameter after cuff release relative to baseline vessel diameter [118], with a low percentage indicating poor endothelial function [113]. FMD is typically carried out in the brachial artery using high resolution ultrasound to assess the vessel diameter, but other arteries such as the radial and femoral artery have also been used to measure FMD [117]. Another method to quantify the dilation is strain-gauge plethysmography, with the strain-gauge detecting the change in arm circumference following an increase in blood flow [119].

The protocol used for FMD is important as both occlusion duration and cuff placement have been shown to influence FMD. Five minutes of limb occlusion is adequate to evoke endothelium-dependent dilatation, with longer cuff durations showing a non-NO response [120]. Similarly, the placement of the cuff around the wrist is dependent on NO, whereas cuff placement on the upper arm is only partially mediated by NO [121]. Further, FMD responses can be affected by external factors such as sleep deprivation [122], hyperhomocysteinemia [123], caffeine [124], smoking [125], antioxidant therapy [126], menstrual cycle [127] and time of day [128]. Accordingly, it is important to control these factors [116].

\section{b) Glyceryl Trinitrate}

As described earlier, GTN produces dilation of the vessel by acting directly on the smooth muscle cells [15]. As such, the vasodilatory response to activated smooth muscle cells can be assessed by GTN administration. GTN is commonly administered as a vasodilator to cardiac patients presenting with angina as a tablet or oral spray, both of which are placed or sprayed directly under the tongue. Typically, the assessment is carried out for 3-4 minutes, which is the time necessary for the vessels to reach peak dilatation [129].

\section{c) Arterial Stiffness}

Each time the heart contracts pressure waves are sent throughout the vasculature and the compliant arterial wall serves to dampen pressure oscillations that stem from the aortic root to aid smooth delivery of bloodflow to the tissues [9]. When the pressure waves reach branch points in the vasculature they are reflected back towards the heart. In a healthy individual the wave arrives during diastole to aid filling of the coronary vessels. However, in individuals with reduced arterial elasticity the pressure wave returns to the heart much quicker and arrives during the systolic phase of the cardiac cycle. This serves to augment the afterload (the pressure the heart has to overcome to open the aortic semilunar valve) [8]. Some notable complications of arterial stiffness include insufficient myocardial perfusion leading to angina or a myocardial infarction, and left ventricular hypertrophy which may result in heart failure [130]. It is therefore not surprising that assessments of arterial stiffness are associated with a number of CVD risk factors such as ageing, smoking, hypertension and dyslipidaemia [130]. Stiffening of the vascular wall can occur due to a reduction in NO production from endothelial cells, loss of smooth muscle tone [131], as well as degeneration of elastin fibres and increased collagen deposition in the vascular wall [132]. Consequently, arterial stiffness is dependent on functional and structural changes in the vasculature.

A number of techniques can be used to assess arterial stiffness non-invasively from the peripheral circulation. The most widely used techniques at present are pulse wave analysis (PWA) and pulse wave velocity (PWV) due to their good reproducibility and ease of use [133]. These assessments have been reported to associate with coronary microvascular endothelial function [134]. PWA is the single measurement of radial artery pressure waveforms which are recorded using a transducer which flattens but not occludes the artery (applanation tonometery). The waveforms are calibrated against the standard brachial blood pressure which gives the maximum (systolic) and minimum (diastolic) points of the pressure curve. The pressure waveform is then mathematically transformed into a central aortic waveform which contains the first and second systolic peaks and displays the augmentation index (AIx). AIx is calculated as the difference between the second and first systolic peaks and is expressed as a percentage of the pulse pressure, with a high value indicating greater arterial stiffness [135]. To obtain PWV readings, arterial pressure waveforms are simultaneously derived from two arteries, usually the carotid and radial arteries, using an applanation tonometer. The distance between the two arteries is then measured and the wave transit time between these two points is recorded to give a quan- 
tifiable PWV, with a greater PWV indicating quicker wave reflection back towards the heart and therefore greater arterial stiffness [136].

\section{d) Carotid Intima-Media Thickness}

Assessment of carotid-intima media thickness (cIMT) using B-mode ultrasound was first introduced in 1986 by Pignoli and colleagues [137]. The assessment detects thickening of the medial layer of the vascular wall and is a good predictor of cardiac events in patients with early atherosclerosis [138], and is also an important predictor for restenosis in patients who have undergone percutaneous coronary intervention [139]. In addition, increased cIMT has been reported to relate to a number of classical CVD risk factors such as ageing, hypertension, and dyslipidemia [140]. Changes in cIMT represents a sequence of events resulting from a decrease in NO bioavailability as well as an increase in ET-1 levels, which over time increase production of inflammatory cytokines, free radicals, adhesion molecules and thrombotic factors leading to smooth muscle proliferation [141, 142]. Assessment of cIMT is typically performed in the common carotid artery, internal carotid artery and at carotid bifurcation points [143], and each site has a similar ability to predict future cardiovascular events [144].

\section{ENDOTHELIAL DYSFUNCTION IN SELECTED CLINICAL POPULATIONS}

\section{a) Endothelial Dysfunction and Cardiovascular Disease}

Endothelial dysfunction is evident before the presentation of obstructive atherosclerotic lesions in both conduit and resistance coronary vessels [145], and can even occur in children with a family history of cardiovascular disease [118]. The magnitude of ED increases in line with the accumulation of CVD risk factors in peripheral conduit vessels [146]. Furthermore, endothelial function is a good prognostic marker of future cardiac events in patients with CVD [99]. Administration of ${ }_{\mathrm{L}}$-arginine can increase $\mathrm{NO}$ bioavailability and improve endothelial function in patients with CVD risk factors [147]. In addition, medications that control CVD risk factors like anti-hypertensives or statins may also have beneficial effects on endothelial function primarily through decreasing oxidative stress and lipid accumulation [101].

\section{b) Endothelial Dysfunction and Hypertension}

In hypertension, the delicate balance between vasodilators and vasoconstrictors produced by the endothelium is disrupted, with disturbance in the NO pathway leading to predominance of vasoconstrictors like ET-1, which contribute to high blood pressure [148]. Even though it is still unclear whether ED is the cause or the consequence of elevated blood pressure, it appears to be an essential factor in hypertension [149]. Studies in humans have reported a significant impairment of the vasodilator response of small resistance vessels to $\mathrm{ACh}$, but not to SNP, in hypertensive patients [150]. Additionally, impaired FMD in the conduit vessels identifies hypertensive patients at increased risk for non-fatal and fatal cardiovascular events [151], whereas the AIx is a predictor of cardiovascular mortality in subjects with essential hypertension [152]. Treatment with angiotensinconverting enzyme (ACE) inhibitors have been shown to improve endothelial function [153]. ACE inhibitors reduce oxidative stress and stimulate bradykinin to help increase NO bioavailability [154].

\section{c) Endothelial Dysfunction and Diabetes}

Individuals with type I and type II diabetes have evidence of both microvascular and macrovascular ED [155]. ED can even be evident in healthy individuals with a family history of diabetes [156], suggesting a genetic link. Patients with diabetes often have reduced NO bioavailability which results from increased oxidative stress [157], and oxidation of LDL due to hyperglycaemia [158]. Patients with type 1 diabetes have shown improved endothelial function when taking ACE inhibitors [159], through a reduction in oxidative stress, and an increase in NO bioavailability [154].

\section{d) Endothelial Dysfunction and Inflammatory Diseases}

Patients with a variety of inflammatory disorders such as rheumatoid arthritis, bechet's disease and inflammatory bowel disease are also at an increased risk for developing CVD [160-163]. In RA, the severity of inflammation can impact on the extent of ED [164]. Assessments of carotid atherosclerosis appear to have good prognostic value in patients with inflammatory diseases [165, 166], and as such their use to determine CVD risk has been advocated in such conditions [167]. Use of anti-inflammatory medications can improve endothelial function in the resistance and conduit vessels $[168,169]$, which further supports the role of inflammation as an important predictor of CVD in inflammatory diseases [170].

\section{SUMMARY}

The endothelium is important in maintaining vascular homeostasis and preventing the development of atherosclerosis. However, perturbation of its activity may lead to ED which, if left untreated, could progress to atherosclerotic lesion formation and subsequent cardiac events. Therefore, assessing endothelial function in patients at risk of cardiovascular disease is important to identify vascular abnormalities and may help monitor strategies and interventions that can improve endothelial function and lower CVD risk.

\section{REFERENCES}

[1] Galley HF, Webster NR. Physiology of the endothelium. Br J Anaesth 2004; 93: 105-13.

[2] Lerman A, Zeiher AM. Endothelial Function: Cardiac Events. Circulation 2005; 111: 363-8.

[3] Ghitescu L, Robert M. Diversity in unity: the biochemical composition of the endothelial cell surface varies between the vascular beds. Microsc Res Tech 2002; 57: 381-9.

[4] Rhodin JAG. Architecture of the vessel wall. In: Bohr DF, Somlyo AP, Sparks JR HV, Gieger SR, editors. Handbook of Physiology: The Cardiovascular System. The Williams and Wilkins Company 1980. p. 1-31.

[5] Ferrer M, Encabo A, Conde MV, Marin J, Balfagon G. Heterogeneity of endothelium-dependent mechanisms in different rabbit arteries. J Vasc Res 1995; 32: 339-46.

[6] Thorin E, Shatos MA, Shreeve SM, Walters CL, Bevan JA. Human vascular endothelium heterogeneity. A comparative study of cerebral and peripheral cultured vascular endothelial cells. Stroke 1997; 28: $375-81$.

[7] Hill CE, Phillips JK, Sandow SL. Heterogeneous control of blood flow amongst different vascular beds. Med Res Rev 2001; 21: 1-60.

[8] Levick JR. An Introduction to Cardiovascular Physiology. Fourth Ed. Oxford University Press 2003.

[9] McEniery CM, Wilkinson IB, Avolio AP. Age, hypertension and arterial function. Clin Exp Pharmacol Physiol 2007; 34: 665-71. 
[10] Pugsley MK, Tabrizchi R. The vascular system: An overview of structure and function. J Pharmacol Toxicol Methods 2000; 44: 333-40.

[11] Davies PF. Flow-mediated endothelial mechanotransduction. Physiol Rev 1995; 75: 519-60.

[12] Aird WC. Phenotypic heterogeneity of the endothelium: II. Representative vascular beds. Circ Res 2007; 100: 174-90.

[13] Ganong WF. Review of Medical Physiology. Twenty Second ed. McGraw Hill Medical; 2003.

[14] Furchgott RF, Zawadzki JV. The obligatory role of endothelial cells in the relaxation of arterial smooth muscle by acetylcholine. Nature 1980; 288: 373-6.

[15] Vallance P, Collier J, Moncada S. Effects of endothelium-derived nitric oxide on peripheral arteriolar tone in man. Lancet 1989; 2: 997-1000.

[16] Palmer RM, Ashton DS, Moncada S. Vascular endothelial cells synthesize nitric oxide from L-arginine. Nature 1988; 333: 664-6.

[17] Prast H, Philippu A. Nitric oxide as modulator of neuronal function. Progress Neurobiol 2001; 64: 51-68.

[18] Michel T, Feron O. Nitric oxide synthases: which, where, how, and why? J Clin Invest 1997; 100: 2146-52.

[19] Lamas S, Marsden PA, Li GK, Tempst P, Michel T. Endothelial nitric oxide synthase: molecular cloning and characterization of a distinct constitutive enzyme isoform. Proc Natl Acad Sci USA 1992; 89: 6348-52.

[20] Balligand JL, Kobzik L, Han X, et al. Nitric Oxide-dependent Parasympathetic Signaling Is Due to Activation of Constitutive Endothelial (Type III) Nitric Oxide Synthase in Cardiac Myocytes. J Biol Chem 1995; 270: 14582-6.

[21] Arnal JF, nh-Xuan AT, Pueyo M, Darblade B, Rami J. Endothelium-derived nitric oxide and vascular physiology and pathology. Cell Mol Life Sci 1999; 55: 1078-87.

[22] Bucci M, Gratton JP, Rudic RD, et al. In vivo delivery of the caveolin-1 scaffolding domain inhibits nitric oxide synthesis and reduces inflammation. Nat Med 2000; 6: 1362-7.

[23] Bae SW, Kim HS, Cha YN, Park YS, Jo SA, Jo I. Rapid increase in endothelial nitric oxide production by bradykinin is mediated by protein kinase A signaling pathway. Biochem Biophys Res Commun 2003; 306: 981-7.

[24] Moncada S, Higgs EA. The discovery of nitric oxide and its role in vascular biology. Br J Pharmacol 2006; 147(Suppl 1): S193-S201.

[25] Schilling WP, Cabello OA, Rajan L. Depletion of the inositol 1,4,5-trisphosphate-sensitive intracellular $\mathrm{Ca} 2+$ store in vascular endothelial cells activates the agonist-sensitive $\mathrm{Ca}(2+)$-influx pathway. Biochem J 1992; 284 : 521-30.

[26] Schilling WP, Elliott SJ. Ca2+ signaling mechanisms of vascular endothelial cells and their role in oxidant-induced endothelial cell dysfunction. Am J Physiol 1992; 262: H1617-H1630.

[27] Putney JW, Jr. A model for receptor-regulated calcium entry. Cell Calcium 1986; 7: 1-12.

[28] Fleming I, Busse R. Signal transduction of eNOS activation. Cardiovascul Res 1999; 43: 532-41.

[29] Butt E, Bernhardt M, Smolenski A, et al. Endothelial nitric-oxide synthase (type III) is activated and becomes calcium independent upon phosphorylation by cyclic nucleotide-dependent protein kinases. J Biol Chem 2000; 275: 5179-87.

[30] Boo YC, Sorescu G, Boyd N, et al. Shear Stress Stimulates Phosphorylation of Endothelial Nitric-oxide Synthase at Ser1179 by Akt-independent Mechanisms. ROLE OF PROTEIN KINASE A. J Biol Chem 2002; 277: 3388-96.

[31] Tran QK, Ohashi K, Watanabe H. Calcium signalling in endothelial cells. Cardiovasc Res 2000; 48: 13-22.

[32] Moens AL, Goovaerts I, Claeys MJ, Vrints CJ. Flow-Mediated Vasodilation: A Diagnostic Instrument, or an Experimental Tool? Chest 2005; 127: 2254-63.

[33] Kuchan MJ, Frangos JA. Role of calcium and calmodulin in flowinduced nitric oxide production in endothelial cells. Am J Physiol Cell Physiol 1994; 266: C628-C636.

[34] Pittner J, Wolgast M, Casellas D, Persson AE. Increased shear stress-released NO and decreased endothelial calcium in rat isolated perfused juxtamedullary nephrons. Kidney Int 2005; 67: 22736.

[35] Ignarro LJ, Harbison RG, Wood KS, Kadowitz PJ. Activation of purified soluble guanylate cyclase by endothelium-derived relaxing factor from intrapulmonary artery and vein: stimulation by acetyl- choline, bradykinin and arachidonic acid. J Pharmacol Exp Ther 1986; 237(3): 893-900.

[36] Jones KA, Wong GY, Jankowski CJ, Akao M, Warner DO. cGMP modulation of $\mathrm{Ca} 2+$ sensitivity in airway smooth muscle. Am J Physiol Lung Cell Mol Physiol 1999; 276: L35-L40.

[37] Collins P, Griffith TM, Henderson AH, Lewis MJ. Endotheliumderived relaxing factor alters calcium fluxes in rabbit aorta: a cyclic guanosine monophosphate-mediated effect. J Physiol 1986; 381: 427-37.

[38] Cornwell TL, Pryzwansky KB, Wyatt TA, Lincoln TM. Regulation of sarcoplasmic reticulum protein phosphorylation by localized cyclic GMP-dependent protein kinase in vascular smooth muscle cells. Mol Pharmacol 1991; 40: 923-31.

[39] Rees DD, Palmer RM, Moncada S. Role of endothelium-derived nitric oxide in the regulation of blood pressure. Proc Natl Acad Sci USA 1989 ; 86 : 3375-8.

[40] Ignarro LJ, Buga GM, Byrns RE, Wood KS, Chaudhuri G. Endothelium-derived relaxing factor and nitric oxide possess identical pharmacologic properties as relaxants of bovine arterial and venous smooth muscle. J Pharmacol Exp Ther 1988; 246: 218-26.

[41] Feelisch M, Noack E, Schroder H. Explanation of the discrepancy between the degree of organic nitrate decomposition, nitrite formation and guanylate cyclase stimulation. Eur Heart J 1988; 9(Suppl A): 57-62.

[42] Marks GS, McLaughlin BE, Brown LB, et al. Interaction of glyceryl trinitrate and sodium nitroprusside with bovine pulmonary vein homogenate and 10,000 x g supernatant: biotransformation and nitric oxide formation. Can J Physiol Pharmacol 1991; 69: 889-92.

[43] Kleschyov AL, Oelze M, Daiber A, et al. Does nitric oxide mediate the vasodilator activity of nitroglycerin? Circ Res 2003; 93: e104e112.

[44] Tian Y, Zhang C, Fang Z, Betts WH. A hypothesis on the metabolism of glyceryl trinitrate in vascular endothelial cells. Clin Chim Acta 2001; 313: 51-7.

[45] Kubes P, Suzuki M, Granger DN. Nitric oxide: an endogenous modulator of leukocyte adhesion. Proc Natl Acad Sci USA 1991; 88: 4651-5.

[46] Nong Z, Hoylaerts M, Van Pelt N, Collen D, Janssens S. Nitric Oxide Inhalation Inhibits Platelet Aggregation and PlateletMediated Pulmonary Thrombosis in Rats. Circ Res 1997; 81: 8659.

[47] Lefer DJ, Jones SP, Girod WG, et al. Leukocyte-endothelial cell interactions in nitric oxide synthase-deficient mice. Am J Physiol 1999; 276: H1943-H1950.

[48] Chauhan SD, Seggara G, Vo PA, MacAllister RJ, Hobbs AJ, Ahluwalia A. Protection against lipopolysaccharide-induced endothelial dysfunction in resistance and conduit vasculature of iNOS knockout mice. FASEB J 2003; 17: 773-5.

[49] Peng HB, Spiecker M, Liao JK. Inducible nitric oxide: an autoregulatory feedback inhibitor of vascular inflammation. J Immunol 1998; 161: 1970-6.

[50] Ahluwalia A, Foster P, Scotland RS, et al. Antiinflammatory activity of soluble guanylate cyclase: cGMP-dependent down-regulation of P-selectin expression and leukocyte recruitment. Proc Natl Acad Sci USA 2004; 101(5): 1386-91.

[51] Bunting S, Moncada S, Vane JR. The prostacyclin--thromboxane A2 balance: pathophysiological and therapeutic implications. $\mathrm{Br}$ Med Bull 1983; 39: 271-6.

[52] Flavahan NA. Balancing prostanoid activity in the human vascular system. Trends Pharmacol Sci 2007; 28: 106-10.

[53] FitzGerald GA. Mechanisms of platelet activation: thromboxane A2 as an amplifying signal for other agonists. Am J Cardiol 1991; 68: 11B-5B.

[54] Needleman P, Isakson PC. The discovery and function of COX-2. J Rheumatol Suppl 1997; 49: 6-8.

[55] McAdam BF, Catella-Lawson F, Mardini IA, Kapoor S, Lawson JA, FitzGerald GA. Systemic biosynthesis of prostacyclin by cyclooxygenase (COX)-2: the human pharmacology of a selective inhibitor of COX-2. Proc Natl Acad Sci USA 1999; 96: 272-7.

[56] Coleman RA, Smith WL, Narumiya S. International Union of Pharmacology classification of prostanoid receptors: properties, distribution, and structure of the receptors and their subtypes Pharmacol Rev 1994; 46(2): 205-29.

[57] Nicosia S, Oliva D, Noe MA, Corsini A, Folco GC, Fumagalli R. PGI2 receptors in vasculature and platelets: 5Z-carbacyclin dis- 
criminates between them. Adv Prostaglandin Thromboxane Leukot Res 1987; 17A: 474-8.

[58] Chow KB, Jones RL, Wise H. Protein kinase A-dependent coupling of mouse prostacyclin receptors to $\mathrm{Gi}$ is cell-type dependent. Eur J Pharmacol 2003; 474: 7-13.

[59] Billington CK, Penn RB. Signaling and regulation of G proteincoupled receptors in airway smooth muscle. Respir Res 2003; 4: 2 .

[60] Stitham J, Stojanovic A, Ross LA, Blount AC Jr, Hwa J. Clusters of transmembrane residues are critical for human prostacyclin receptor activation. Biochemistry 2004; 43: 8974-86.

[61] Fetalvero KM, Martin KA, Hwa J. Cardioprotective prostacyclin signaling in vascular smooth muscle. Prostaglandins \&Other Lipid Mediators 2007; 82: 109-18.

[62] Verma S, Raj SR, Shewchuk L, Mather KJ, Anderson TJ. Cyclooxygenase-2 blockade does not impair endothelial vasodilator function in healthy volunteers: randomized evaluation of rofecoxib versus naproxen on endothelium-dependent vasodilatation. Circulation 2001; 104: 2879-82.

[63] Beverelli F, Bea ML, Puybasset L, Giudicelli JF, Berdeaux A. Chronic inhibition of NO synthase enhances the production of prostacyclin in coronary arteries through upregulation of the cyclooxygenase type 1 isoform. Fundam Clin Pharmacol 1997; 11: 252-9.

[64] Thomas DW, Mannon RB, Mannon PJ, et al. Coagulation defects and altered hemodynamic responses in mice lacking receptors for thromboxane A2. J Clin Invest 1998; 102: 1994-2001.

[65] Alexander RW, Griendling KK. Signal transduction in vascular smooth muscle. J Hypertens Suppl 1996; 14: S51-S54.

[66] Masferrer JL, Zweifel BS, Manning PT, et al. Selective inhibition of inducible cyclooxygenase 2 in vivo is antiinflammatory and nonulcerogenic. Proc Natl Acad Sci USA 1994; 91: 3228-32.

[67] Marwali MR, Mehta JL. COX-2 inhibitors and cardiovascular risk. Inferences based on biology and clinical studies. Thromb Haemost 2006; 96: 401-6.

[68] Alonso D, Radomski MW. The nitric oxide-endothelin-1 connection. Heart Fail Rev 2003; 8: 107-15.

[69] Yanagisawa M, Kurihara H, Kimura S, et al. A novel potent vasoconstrictor peptide produced by vascular endothelial cells. Nature 1988; 332(6163): 411-5.

[70] Davenport AP, Kuc RE, Maguire JJ, Harland SP. ETA receptors predominate in the human vasculature and mediate constriction. J Cardiovasc Pharmacol 1995; 26(Suppl 3): S265-S267.

[71] Bacon CR, Cary NR, Davenport AP. Distribution of endothelin receptors in atherosclerotic human coronary arteries. J Cardiovasc Pharmacol 1995; 26(Suppl 3): S439-S441.

[72] Kedzierski RM, Yanagisawa M. Endothelin system: the doubleedged sword in health and disease. Annu Rev Pharmacol Toxicol 2001; 41: 851-76.

[73] deNucci G, Thomas R, Orleans-Juste P, et al. Pressor effects of circulating endothelin are limited by its removal in the pulmonary circulation and by the release of prostacyclin and endotheliumderived relaxing factor. Proc Natl Acad Sci USA 1988; 85: 9797800 .

[74] Cardillo C, Kilcoyne CM, Cannon RO, III, Panza JA. Interactions between nitric oxide and endothelin in the regulation of vascular tone of human resistance vessels in vivo. Hypertension 2000; 35: 1237-41.

[75] Dagassan PH, Breu V, Clozel M, et al. Up-regulation of endothelin-B receptors in atherosclerotic human coronary arteries. J Cardiovasc Pharmacol 1996; 27: 147-53.

[76] Bohm F, Ahlborg G, Johansson BL, Hansson LO, Pernow J. Combined endothelin receptor blockade evokes enhanced vasodilatation in patients with atherosclerosis. Arterioscler Thromb Vasc Biol 2002; 22: 674-9.

[77] Verhaar MC, Strachan FE, Newby DE, et al. Endothelin-A receptor antagonist-mediated vasodilatation is attenuated by inhibition of nitric oxide synthesis and by endothelin-B receptor blockade. Circulation 1998; 97: 752-6.

[78] Pernow J, Gonon AT, Gourine A. The role of the endothelium for reper fusion injury. Eur Heart J Suppl 2001; 3 : C22-C27.

[79] Davie N, Haleen SJ, Upton PD, et al. ET(A) and ET(B) receptors modulate the proliferation of human pulmonary artery smooth muscle cells. Am J Respir Crit Care Med 2002; 165: 398-405.

[80] Yahiaoui L, Villeneuve A, Valderrama-Carvajal H, Burke F, Fixman ED. Endothelin-1 regulates proliferative responses, both alone and synergistically with PDGF, in rat tracheal smooth muscle cells. Cell Physiol Biochem 2006; 17: 37-46.

[81] Bots ML, Hoes AW, Koudstaal PJ, Hofman A, Grobbee DE. Common carotid intima-media thickness and risk of stroke and myocardial infarction: The Rotterdam Study. Circulation 1997; 96(5): 1432-7.

[82] Maguire JJ, Yu JC, Davenport AP. ETA receptor antagonists inhibit intimal smooth muscle cell proliferation in human vessels. Clin Sci (Lond) 2002; $103: 184 S-8 S$.

[83] Kowala MC, Rose PM, Stein PD, et al. Selective blockade of the endothelin subtype A receptor decreases early atherosclerosis in hamsters fed cholesterol. Am J Pathol 1995; 146: 819-26.

[84] Feletou M, Vanhoutte PM. Endothelium-dependent hyperpolarization of canine coronary smooth muscle. Br J Pharmacol 1988; 93 : 515-24.

[85] Cohen RA, Vanhoutte PM. Endothelium-Dependent Hyperpolarization : Beyond Nitric Oxide and Cyclic GMP. Circulation 1995; 92: 3337-49.

[86] Feletou M, Vanhoutte PM. Endothelium-derived hyperpolarizing factor: where are we now? Arterioscler Thromb Vasc Biol 2006; 26: $1215-25$.

[87] Scotland RS, Madhani M, Chauhan S, et al. Investigation of Vascular Responses in Endothelial Nitric Oxide Synthase/ Cyclooxygenase-1 Double-Knockout Mice: Key Role for Endothelium-Derived Hyperpolarizing Factor in the Regulation of Blood Pressure in Vivo. Circulation 2005; 111: 796-803.

[88] Edwards G, Weston AH. Potassium and potassium clouds in endothelium-dependent hyperpolarizations. Pharmacol Res 2004; 49: 535-41.

[89] Edwards G, Dora KA, Gardener MJ, Garland CJ, Weston AH. K+ is an endothelium-derived hyperpolarizing factor in rat arteries. $\mathrm{Na}$ ture 1998; 396: 269-72.

[90] Quilley J, McGiff JC. Is EDHF an epoxyeicosatrienoic acid? Trends Pharmacol Sci 2000; 21: 121-4.

[91] Campbell WB, Gebremedhin D, Pratt PF, Harder DR. Identification of epoxyeicosatrienoic acids as endothelium-derived hyperpolarizing factors. Circ Res 1996; 78: 415-23.

[92] Gauthier KM, Deeter C, Krishna UM, et al. 14,15-Epoxyeicosa5(Z)-enoic acid: a selective epoxyeicosatrienoic acid antagonist that inhibits endothelium-dependent hyperpolarization and relaxation in coronary arteries. Circ Res 2002; 90: 1028-36.

[93] Petersson J, Zygmunt PM, Hogestatt ED. Characterization of the potassium channels involved in EDHF-mediated relaxation in cerebral arteries. Br J Pharmacol 1997; 120: 1344-50.

[94] Sandow SL, Hill CE. Incidence of myoendothelial gap junctions in the proximal and distal mesenteric arteries of the rat is suggestive of a role in endothelium-derived hyperpolarizing factor-mediated responses. Circ Res 2000; 86: 341-6.

[95] Bryan RM Jr, You J, Golding EM, Marrelli SP. Endotheliumderived hyperpolarizing factor: a cousin to nitric oxide and prostacyclin. Anesthesiology 2005; 102: 1261-77.

[96] Anderson TJ, Uehata A, Gerhard MD, et al. Close relation of endothelial function in the human coronary and peripheral circulations. $J$ Am Coll Cardiol 1995; 26: 1235-41.

[97] Takase B, Hamabe A, Satomura K, et al. Close relationship between the vasodilator response to acetylcholine in the brachial and coronary artery in suspected coronary artery disease. International J Cardiol 2005; 105: 58-66.

[98] Khan F, Patterson D, Belch JJ, Hirata K, Lang CC. Relationship between peripheral and coronary function using laser Doppler imaging and transthoracic echocardiography. Clin Sci (Lond) 2008; 115: 295-300.

[99] Gokce N, Keaney JF Jr, Hunter LM, et al. Predictive value of noninvasively determined endothelial dysfunction for long-term cardiovascular events in patients with peripheral vascular disease. J Am Coll Cardiol 2003; 41: 1769-75.

[100] Rossi R, Nuzzo A, Origliani G, Modena MG. Prognostic role of flow-mediated dilation and cardiac risk factors in post-menopausal women. J Am Coll Cardiol 2008; 51: 997-1002.

[101] Widlansky ME, Gokce N, Keaney J, Vita JA. The clinical implications of endothelial dysfunction. J Am Coll Cardiol 2003; 42(7): 1149-60.

[102] Sloan JB, Soltani K. Iontophoresis in dermatology. A review. J Am Acad Dermatol 1986; 15: 671-84.

[103] Kalia YN, Naik A, Garrison J, Guy RH. Iontophoretic drug delivery. Adv Drug Deliv Rev 2004; 56: 619-58. 
[104] Morris SJ, Shore AC. Skin blood flow responses to the iontophoresis of acetylcholine and sodium nitroprusside in man: possible mechanisms. J Physiol 1996; 496 : 531-42.

[105] Cracowski JL, Minson CT, Salvat-Melis M, Halliwill JR. Methodological issues in the assessment of skin microvascular endothelial function in humans. Trends Pharmacol Sci 2006; 27: 503-8.

[106] Berardesca E, Leveque JL, Masson P. EEMCO guidance for the measurement of skin microcirculation. Skin Pharmacol Appl Skin Physiol 2002; 15: 442-56.

[107] Ferrell WR, Ramsay JE, Brooks N, et al. Elimination of electrically induced iontophoretic artefacts: implications for non-invasive assessment of peripheral microvascular function. J Vasc Res 2002; 39: 447-55.

[108] Droog EJ, Henricson J, Nilsson GE, Sjoberg F. A protocol for iontophoresis of acetylcholine and sodium nitroprusside that minimises nonspecific vasodilatory effects. Microvasc Res 2004; 67(2): 197-202.

[109] Elherik K, Khan F, McLaren M, Kennedy G, Belch JJF. Circadian variation in vascular tone and endothelial cell function in normal males. Clin Sci 2002; 102: 547-52.

[110] Williams MRI, Westerman RA, Kingwell BA, et al. Variations in Endothelial Function and Arterial Compliance during the Menstrual Cycle. J Clin Endocrinol Metab 2001; 86(11): 5389-95.

[111] Turner J, Belch JJ, Khan F. Current concepts in assessment of microvascular endothelial function using laser Doppler imaging and iontophoresis. Trends Cardiovasc Med 2008; 18: 109-16.

[112] Wilkinson IB, Webb DJ. Venous occlusion plethysmography in cardiovascular research: methodology and clinical applications. Br J Clinical Pharmacol 2001; 52: 631-46.

[113] Deanfield J, Donald A, Ferri C, et al. Endothelial function and dysfunction. Part I: Methodological issues for assessment in the different vascular beds: a statement by the Working Group on Endothelin and Endothelial Factors of the European Society of Hypertension. J Hypertens 2005; 23: 7-17.

[114] Cutolo M, Sulli A, Secchi ME, Paolino S, Pizzorni C. Nailfold capillaroscopy is useful for the diagnosis and follow-up of autoimmune rheumatic diseases. A future tool for the analysis of microvascular heart involvement? Rheumatology 2006; 45: iv43-iv46.

[115] Celermajer DS. Endothelial Dysfunction: Does It Matter? Is It Reversible? J Am Coll Cardiol 1997; 30: 325-33.

[116] Corretti MC, Anderson TJ, Benjamin EJ, et al. Guidelines for the ultrasound assessment of endothelial-dependent flow-mediated vasodilation of the brachial artery: A report of the International Brachial Artery Reactivity Task Force. J Am Coll Cardiol 2002; 39: 257-65.

[117] Joannides R, Haefeli WE, Linder L, et al. Nitric oxide is responsible for flow-dependent dilatation of human peripheral conduit arteries in vivo. Circulation 1995; 91: 1314-9.

[118] Celermajer DS, Sorensen KE, Gooch VM, et al. Non-invasive detection of endothelial dysfunction in children and adults at risk of atherosclerosis. Lancet 1992; 340: 1111-5.

[119] Alam TA, Seifalian AM, Baker D. A Review of Methods Currently Used for Assessment of In vivo Endothelial Function. Eur J Vasc Endovasc Surg 2005; 29: 269-76.

[120] Mullen MJ, Kharbanda RK, Cross J, et al. Heterogenous Nature of Flow-Mediated Dilatation in Human Conduit Arteries In Vivo : Relevance to Endothelial Dysfunction in Hypercholesterolemia. Circ Res 2001; 88: 145-51.

[121] Doshi SN, Naka KK, Payne N, et al. Flow-mediated dilatation following wrist and upper arm occlusion in humans: the contribution of nitric oxide. Clin Sci (Lond) 2001; 101: 629-35.

[122] Takase B, Akima T, Uehata A, Ohsuzu F, Kurita A. Effect of chronic stress and sleep deprivation on both flow-mediated dilation in the brachial artery and the intracellular magnesium level in humans. Clin Cardiol 2004; 27: 223-7.

[123] Chambers JC, McGregor A, Jean-Marie J, Obeid OA, Kooner JS. Demonstration of rapid onset vascular endothelial dysfunction after hyperhomocysteinemia: an effect reversible with vitamin $\mathrm{C}$ therapy. Circulation 1999; 99: 1156-60.

[124] Papamichael CM, Aznaouridis KA, Karatzis EN, et al. Effect of coffee on endothelial function in healthy subjects: the role of caffeine. Clin Sci (Lond) 2005; 109: 55-60.

[125] Lekakis J, Papamichael C, Vemmos C, et al. Effect of acute cigarette smoking on endothelium-dependent brachial artery dilatation in healthy individuals. Am J Cardiol 1997; 79: 529-31.
[126] Engler MM, Engler MB, Malloy MJ, et al. Antioxidant Vitamins C and E Improve Endothelial Function in Children With Hyperlipidemia: Endothelial Assessment of Risk from Lipids in Youth (EARLY) Trial. Circulation 2003; 108: 1059-63.

[127] Hashimoto M, Akishita M, Eto M, et al. Modulation of Endothelium-Dependent Flow-Mediated Dilatation of the Brachial Artery by Sex and Menstrual Cycle. Circulation 1995; 92: 3431-5.

[128] Etsuda H, Takase B, Uehata A, et al. Morning attenuation of endothelium-dependent, flow-mediated dilation in healthy young men: possible connection to morning peak of cardiac events? Clin Cardiol 1999; 22: 417-21

[129] Ducharme A, Dupuis J, McNicoll S, Harel F, Tardif JC. Comparison of nitroglycerin lingual spray and sublingual tablet on time of onset and duration of brachial artery vasodilation in normal subjects. Am J Cardiol 1999; 84: 952-4

[130] Nichols WW. Clinical measurement of arterial stiffness obtained from noninvasive pressure waveforms. Am J Hypertens 2005; 18 : 3-10.

[131] Wilkinson IB, Qasem A, McEniery CM, Webb DJ, Avolio AP, Cockcroft JR. Nitric oxide regulates local arterial distensibility in vivo. Circulation 2002; 105: 213-7.

[132] Zieman SJ, Melenovsky V, Kass DA. Mechanisms, pathophysiology, and therapy of arterial stiffness. Arterioscler Thromb Vasc Biol 2005; 25: 932-43.

[133] Wilkinson IB, Fuchs SA, Jansen IM, et al. Reproducibility of pulse wave velocity and augmentation index measured by pulse wave analysis. J Hypertens 1998; 16: 2079-84.

[134] Saito M, Okayama H, Nishimura K, et al. Possible link between large artery stiffness and coronary flow velocity reserve. Heart 2008; 94: e20.

[135] Wilkinson IB, Hall IR, MacCallum H, et al. Pulse-wave analysis: clinical evaluation of a noninvasive, widely applicable method for assessing endothelial function. Arterioscler Thromb Vasc Biol 2002; 22: 147-52.

[136] Oliver JJ, Webb DJ. Noninvasive assessment of arterial stiffness and risk of atherosclerotic events. Arterioscler Thromb Vasc Biol 2003; 23: 554-66.

[137] Pignoli P, Tremoli E, Poli A, Oreste P, Paoletti R. Intimal plus medial thickness of the arterial wall: a direct measurement with ultrasound imaging. Circulation 1986; 74: 1399-406.

[138] Corrado E, Rizzo M, Coppola G, Muratori I, Carella M, Novo S. Endothelial dysfunction and carotid lesions are strong predictors of clinical events in patients with early stages of atherosclerosis: a 24month follow-up study. Coron Artery Dis 2008; 19: 139-44.

[139] Corrado E, Camarda P, Coppola G, et al. Prognostic role of endothelial dysfunction and carotid intima-media thickness in patients undergoing coronary stent implantation. Int Angiol 2009; 28 : $12-9$

[140] Oren A, Vos LE, Uiterwaal CSPM, Grobbee DE, Bots ML. Cardiovascular risk factors and increased carotid intima-media thickness in healthy young adults: The atherosclerosis risk in young adults (ARYA) study. Arch Intern Med 2003; 163: 1787-92.

[141] Wohlin M, Helmersson J, Sundstrom J, et al. Both cyclooxygenase- and cytokine-mediated inflammation are associated with carotid intima-media thickness. Cytokine 2007; 38: 130-6.

[142] Shimizu M, Kohara S, Yamamoto M, Ando Y, Haida M, Shinohara Y. Significant relationship between platelet activation and intramedia thickness of the carotid artery in patients with ischemic cerebrovascular disease. Thromb Res 2006; 117: 647-52.

[143] Ter Avest E, Stalenhoef AF, de Graaf J. What is the role of noninvasive measurements of atherosclerosis in individual cardiovascular risk prediction? Clin Sci (Lond) 2007; 112: 507-16.

[144] Iglesias del SA, Bots ML, Grobbee DE, Hofman A, Witteman JC. Carotid intima-media thickness at different sites: relation to incident myocardial infarction; The Rotterdam Study. Eur Heart J 2002; 23: 934-40.

[145] Ross R. Atherosclerosis - an inflammatory disease. N Engl J Med 1999; 340: 115-26.

[146] Hashimoto M, Kozaki K, Eto M, et al. Association of coronary risk factors and endothelium-dependent flow-mediated dilatation of the brachial artery. Hypertens Res 2000; 23: 233-8.

[147] Creager MA, Gallagher SJ, Girerd XJ, Coleman SM, Dzau VJ, Cooke JP. L-arginine improves endothelium-dependent vasodilation in hypercholesterolemic humans. J Clin Invest 1992; 90: 1248 53 
[148] Nadar S, Blann AD, Lip GY. Endothelial dysfunction: methods of assessment and application to hypertension. Curr Pharm Des 2004; 10: 3591-605.

[149] Panza JA, Quyyumi AA, Brush JE Jr, Epstein SE. Abnormal endothelium-dependent vascular relaxation in patients with essential hypertension. N Engl J Med 1990; 323: 22-7.

[150] Deng LY, Li JS, Schiffrin EL. Endothelium-dependent relaxation of small arteries from essential hypertensive patients: mechanisms and comparison with normotensive subjects and with responses of vessels from spontaneously hypertensive rats. Clin Sci (Lond) 1995; 88: 611-22.

[151] Muiesan ML, Salvetti M, Paini A, et al. Prognostic role of flowmediated dilatation of the brachial artery in hypertensive patients. $\mathbf{J}$ Hypertens 2008; 26: 1612-8.

[152] Safar ME. Pulse pressure, arterial stiffness and wave reflections (augmentation index) as cardiovascular risk factors in hypertension. Ther Adv Cardiovasc Dis 2008; 2: 13-24.

[153] Aznaouridis KA, Stamatelopoulos KS, Karatzis EN, Protogerou AD, Papamichael CM, Lekakis JP. Acute effects of reninangiotensin system blockade on arterial function in hypertensive patients. J Hum Hypertens 2007; 21: 654-63.

[154] Anderson TJ. Assessment and treatment of endothelial dysfunction in humans. J Am Coll Cardiol 1999; 34: 631-8.

[155] Krentz AJ, Clough G, Byrne CD. Interactions between microvascular and macrovascular disease in diabetes: pathophysiology and therapeutic implications. Diabetes Obes Metab 2007; 9: 781-91.

[156] Caballero AE, Arora S, Saouaf R, et al. Microvascular and macrovascular reactivity is reduced in subjects at risk for type 2 diabetes. Diabetes 1999; 48: 1856-62.

[157] Vapaatalo H, Mervaala E. Clinically important factors influencing endothelial function. Med Sci Monit 2001; 7: 1075-85.

[158] Jaap AJ, Shore AC, Tooke JE. Relationship of insulin resistance to microvascular dysfunction in subjects with fasting hyperglycaemia. Diabetologia 1997; 40: 238-43.

[159] Arcaro G, Zenere BM, Saggiani F, et al. ACE inhibitors improve endothelial function in type 1 diabetic patients with normal arterial pressure and microalbuminuria. Diabetes Care 1999; 22: 1536-42.
[160] Kitas GD, Erb N. Tackling ischaemic heart disease in rheumatoid arthritis. Rheumatology (Oxford) 2003; 42: 607-13.

[161] Ozturk MA, Oktar SO, Unverdi S, et al. Morphologic evidence of subclinical atherosclerosis obtained by carotid ultrasonography in patients with Behcet's disease. Rheumatol Int 2006; 26: 867-72.

[162] Dagli N, Poyrazoglu OK, Dagli AF, et al. Is inflammatory bowel disease a risk factor for early atherosclerosis? Angiology 2010; 61: 198-204.

[163] Pahor A, Hojs R, Gorenjak M, Rozman B. Accelerated atherosclerosis in pre-menopausal female patients with rheumatoid arthritis. Rheumatol Int 2006; 27(2): 119-23.

[164] Cleland SJ, Sattar N, Petrie JR, Forouhi NG, Elliott HL, Connell JM. Endothelial dysfunction as a possible link between C-reactive protein levels and cardiovascular disease. Clin Sci (Lond) 2000; 98 : 531-5.

[165] Bilginer Y, Ozaltin F, Basaran C, et al. Evaluation of intima media thickness of the common and internal carotid arteries with inflammatory markers in familial Mediterranean fever as possible predictors for atherosclerosis. Rheumatol Int 2008; 28: 1211-6.

[166] Nagata-Sakurai M, Inaba M, Goto $\mathrm{H}$, et al. Inflammation and bone resorption as independent factors of accelerated arterial wall thickening in patients with rheumatoid arthritis. Arthritis Rheum 2003; 48: 3061-7.

[167] Gasparyan AY. The use of carotid artery ultrasonography in different clinical conditions. Open Cardiovasc Med J 2009; 3: 7880.

[168] Raza K, Carruthers DM, Stevens R, Filer AD, Townend JN, Bacon PA. Infliximab leads to a rapid but transient improvement in endothelial function in patients with primary systemic vasculitis. Ann Rheumatol Dis 2006; 65: 946-8.

[169] Hurlimann D, Forster A, Noll G, et al. Anti-Tumor Necrosis Factor-\{alpha\} Treatment Improves Endothelial Function in Patients With Rheumatoid Arthritis. Circulation 2002; 106: 2184-7.

[170] Gonzalez-Gay MA, Gonzalez-Juanatey C, Martin J. Rheumatoid arthritis: a disease associated with accelerated atherogenesis. Semin Arthritis Rheumatol 2005; 35: 8-17. 